\title{
Numerical Analysis on the Effect of Stoichiometric Ratio on Fuel Utilization and Performance of High Temperature Proton Exchange Membrane Fuel Cells
}

\author{
Shian $\mathrm{Li}^{1}$, Rongqiang Wei ${ }^{1}$, Xinrong $\mathrm{Lv}^{1}$, Weiqiang $\mathrm{Ye}^{2}$, Qiuwan Shen ${ }^{1, *}$, Guogang Yang ${ }^{1, *}$ \\ ${ }^{1}$ Marine Engineering College, Dalian Maritime University, China. \\ ${ }^{2}$ Marine Engineering College, Guangzhou Maritime University, China. \\ *E-mail: shenqiuwan@dlmu.edu.cn and yanggg@dlmu.edu.cn
}

doi: $10.20964 / 2020.08 .51$

Received: 9 April 2020 / Accepted: 25 May 2020 / Published: 10 July 2020

\begin{abstract}
A three-dimensional mathematical model is developed and then employed to examine the effect of stoichiometric ratio on fuel utilization of high temperature proton exchange membrane fuel cells. The effect of stoichiometric ratio on cell performance and transport phenomena is also investigated. The performance of fuel cells at different stoichiometric ratios are obtained and compared. It is found that the cell performance can be improved by increasing the stoichiometric ratio, but it can not be continually increased. And the heat, mass and charge transport processes of fuel cells at different stoichiometric ratios are also presented and compared.
\end{abstract}

Keywords: High temperature proton exchange membrane fuel cells, Stoichiometric ratio, Fuel utilization, Cell performance, Transport characteristics

\section{FULL TEXT}

(C) 2020 The Authors. Published by ESG (www.electrochemsci.org). This article is an open access article distributed under the terms and conditions of the Creative Commons Attribution license (http://creativecommons.org/licenses/by/4.0/). 